\title{
ENTREPRENEURIALISM IN THE GLOBALISING CITY-REGION OF TANGIER, MOROCCO
}

\author{
MIGUEL KANAI \& WILLIAM KUTZ \\ Department of Geography and Regional Studies, University of Miami, Florida, USA. E-mails: \\ miguelkanai@miami.edu; w.kutz@umiami.edu
}

Received: November 2009; revised May 2010

\begin{abstract}
This paper inspects the territorial and state restructuring of the globalising city-region of Tangier. It argues that recent economic growth and transnational connections follow new forms of entrepreneurial development that aggravate social and spatial inequalities. The analysis shows that these forms of urban and regional management are embedded in the neoliberalised, yet monarchcentric Moroccan state. Analysis of local governance arrangements demonstrates the pivotal importance of an elite cadre of urban managers within the monarchic power structure. Fieldwork evidence documents the emergence of megaprojects as preferred vehicles for entrepreneurial development through site observations, indepth interviews and archival research. The Tanger City Center project presents a case that illustrates the social and spatial implications of a restructuring territorial economy and the effects of new polarities being overlaid on existing urban and regional geographies. The paper concludes with a reflection on the comparative and relational lessons that can be drawn from Tangier's restructuring.
\end{abstract}

Key words: urban globalisation, Morocco, case study, entrepreneurialism, city-regions, megaprojects

\section{INTRODUCTION}

The discourse of urban globalisation provides a central explanation to complex transformations evidenced in contemporary cities. It shows that globalisation-led urban and regional change encompasses multiple and interrelated economic, political, cultural and physical processes in a world increasingly integrated through capitalist norms and practices. While initial studies focused on the economic structures and social profiles of a handful of global cities in the capitalist core, the field has expanded to incorporate a wider scope of topics into its research agenda. These include the following: (a) the opportunities and predicaments for globalising cities in non-core regions (Grant \& Short 2002; Machimura 2003; Robinson 2006); (b) the territorial restructur- ing of metropolitan areas and emergence of new urban geographies of inequality and exclusionary built forms (Soja 2000; Graham \& Marvin 2001; Grant \& Nijman 2002); and (c) the socio-political management of such transformations carried through under the hegemony of various forms of neoliberal entrepreneurialism that economic and state elites have embraced (Harvey 1989; Moulaert et al. 2003; Ong 2006).

Contributing to this body of research, the paper analyses the linkages between the institutional and territorial transformations that are reshaping Tangier, which this paper conceptualises as a globalising city-region. Though not located in a core country for the global capitalist economy, Tangier is increasingly showing a transnational orientation in its economic dynamics and political logics (Scott 2001; Grant 
2009, pp. 11-16). We argue that central to the city-region's dynamism and shortcomings is the reliance on large-scale initiatives for territorial development and urban megaprojects. These are the preferred vehicles to harness the perceived benefits of globalisation though foreign investment, trade promotion and tourismrelated revenue generation. Such an entrepreneurial approach to development and redevelopment has imbued the consolidating city-region with economic momentum and is reshaping Tangier's urban and regional geographies. But entrepreneurialism has fallen short of addressing inherited regional unevenness and urban fractures. It has been neglectful of basic social needs and its selective focus on strategic sites and projects is deepening exclusion and producing new spatial injustices.

In order to be properly understood this process must also be located within the reconfigured institutions of the city-region and Moroccan state. Both have arisen from complex interactions between multiple external pressures and localised case-specific responses. A new elite cadre of entrepreneurial urban managers has emerged comprising governmental and private, Moroccan and transnational actors. They are all invested with development objectives and prerequisites unique to the current globalisation era. Within the logics of a re-scaled state (see second section), planners and officials operate within an array of territorially dispersed and administratively fragmented agencies that nevertheless are centrally chartered and controlled by Morocco's monarchy. Such arrangements only feature limited mechanisms for democratic accountability. Necessitated by the imperatives of exogenously-driven entrepreneurial growth, new pivotal roles for international developers and real-estate firms have emerged in the planning and implementation of projects. Produced spatial forms and architectural typologies hence respond to imported models and cater to foreign users while simultaneously ignoring the everyday lives, needs and claims of local populations. In order to support these claims, the analysis employs evidence from fieldwork observations (June-August 2009) including interviews and local governmental secondary sources (policy reports, maps and architectural blueprints).
The paper consists of three sections. The first section assesses socio-spatial inequalities rooted in Tangier since early stages of modern growth in the early twentieth-century. During the colonial period (1923-1956) growth under foreign domination produced a cosmopolitan city with a transnationally-oriented economy, as well as a physically fragmented and socially unequal structure. Regional tensions in the mid- and late-twentieth century resulted in Tangier's neglect by the developmentalist impetus of the newly independent Moroccan state. Since 1983, novel forms of economic growth and regional development have emerged after a period of crisis-generated restructuring and ensuing globalisation.

The second section focuses on state restructuring by noticing a redefinition of governmental and market roles that has occurred under King Mohammed VI, who continues to hold both administrative and political power, and has promoted neoliberalisation as an active state project (Catusse 2008, p. 49). Under the tutelage of his monarchy, new development agencies and public-private partnerships have been created to steer the entrepreneurial globalisation process and expand the increasingly integrated city-region. Priorities have shifted from (a) earlier forms of state-led regional development through import-substitution industrialisation to (b) reliance on strategic nodes to territorialise transnational flows into the urban fabric. Hence, policies now focus on the construction of megaprojects such as the Tanger-Med Port and the Tanger Free Zone. Pressing needs such as deficient basic infrastructure and generalised lack of access to adequate housing remain unheeded.

The third and final section examines the role of foreign city-builders in Tangier through a case study of the Tanger City Center initiative. After the bankruptcy of a previous contractor, this high-profile project of over 175,000 square metres has been entrusted to Inveravante, a transnational conglomerate based in Spain and active throughout Europe, Latin America and Morocco. Inveravante is expected to deliver an internationallymarketable product that will attract investors and visitors. Envisioned as the new core of Tangier's urban life, this project is however inaccessible for most residents. Its location on 
the outer edge of the modern city deepens longstanding divisions with the relegated medina. Concluding remarks touch upon the comparability of this singular case of entrepreneurialism to broaden research agendas on globalising cities and regions (Short et al. 1996). There is also a call for further scrutiny of the socio-political negotiation and contestation of urban development.

\section{OLD AND NEW URBAN INEQUALITIES}

Tangier is a rapidly globalising city-region in North Africa strategically placed at the western entrance to the Strait of Gibraltar, which links the Mediterranean to the Atlantic Ocean (See Figure 1). Fuelled by aggressive investment efforts and market-oriented governmental actions, Tangier's economy has experienced high growth rates and stronger linkages to the global economy since the early 1980s, when it began recovering from long-term stagnation experienced during Morocco's period of import-substitution industrialisation (ISI). Table 1 shows employment doubling (19942006); investment and production tripling; exports increasing almost nine-fold and added value quadrupling. The data also show the external orientation of Tangier's economic dynamism and large productivity gains allowing output to grow almost twice as fast as total employment.

Yet not all have benefited, a social statistics show that for the past decade the officially disclosed unemployment rate has hovered around 10 per cent, while the cost of living has increased steadily particularly in basic categories such as food (which increased by a factor of approximately $25 \%$ ), clothing, transportation and housing (Direction de la Statistique 2010). Moreover, this economic expansion has arguably been accompanied by deepening social inequalities and more visible forms of uneven and fragmentary regional development. Entrepreneurial policies and transnationallyoriented economic expansion produce novel fractures that compound inherited spatial injustices in the built environment. This section situates Tangier's transformation within neoliberal globalisation in Morocco. The context drawn here informs later discussions on the role of local planners and transnational devel-

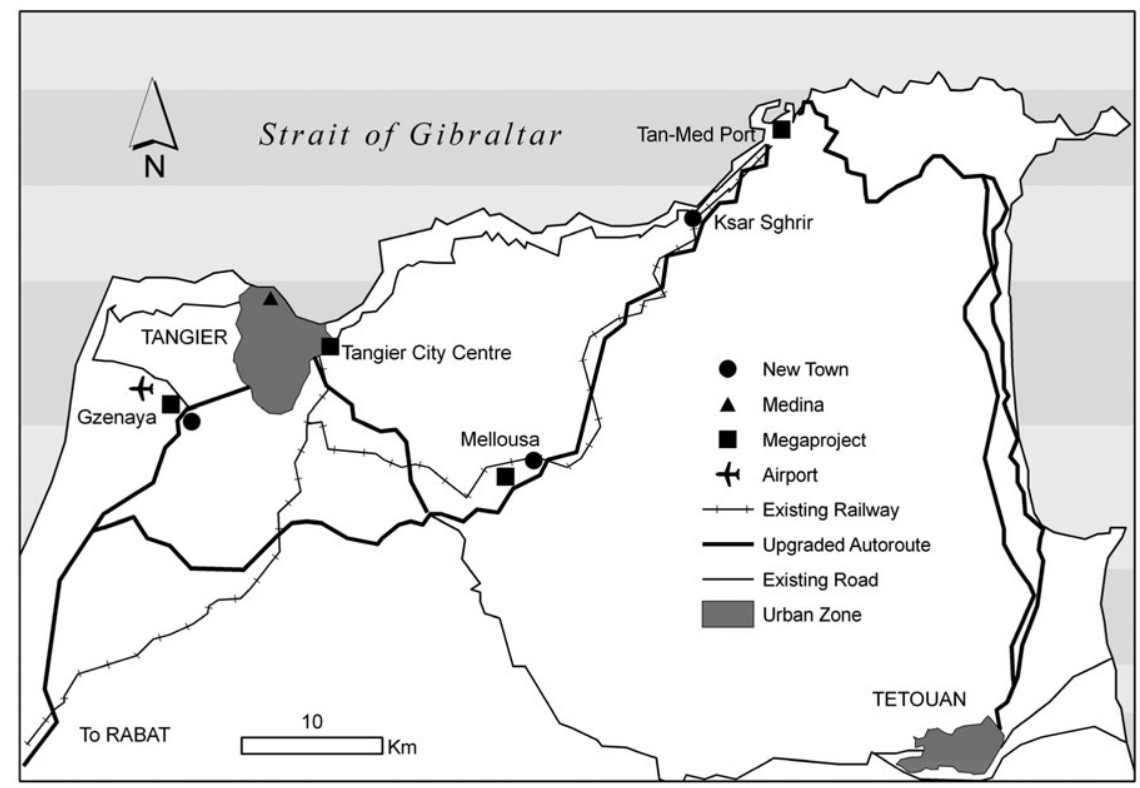

Figure 1. The globalising city-region of Tangier.

Source: Own drawing based on multiple schematic images from Tangier Urban Agency (Agence Urbaine de Tanger) and Tangier Mediterranean Special Agency. 
Table 1. Industrial economic indicators, Tangier-Tétouan, 1994-2006.

\begin{tabular}{lcrrrr}
\hline Year & $\begin{array}{c}\text { Total employment } \\
\text { (permanent and } \\
\text { seasonal) }\end{array}$ & $\begin{array}{c}\text { Production } \\
(1,000 \mathrm{dh})\end{array}$ & $\begin{array}{c}\text { Investment } \\
(1,000 \mathrm{dh})\end{array}$ & $\begin{array}{c}\text { Exports } \\
(1,000 \mathrm{dh})\end{array}$ & $\begin{array}{c}\text { Added value } \\
(1,000 \mathrm{dh})\end{array}$ \\
\hline 1994 & 31,552 & $4,178,604$ & 307,467 & $1,142,732$ & $1,363,421$ \\
1999 & 38,019 & $5,158,771$ & 665,130 & $2,371,566$ & $2,083,082$ \\
2004 & 53,264 & $10,150,576$ & 776,827 & $6,079,169$ & - \\
2006 & 63,281 & $13,741,082$ & $1,053,665$ & $8,950,577$ & $4,058,935$ \\
\hline
\end{tabular}

Source: Own tabulation based on Direction de la Statistique (1994a, 2000, 2005, 2007).

opers in managing and shaping the territorial restructuring of the city-region.

It is first important to remark that, as in other less-developed economies undergoing latetwentieth-century neoliberalisation, economic growth and employment expansion paralleled the worsening of labour conditions and a seemingly paradoxical rise in unemployment throughout Morocco (Cohen \& Jaidi 2006). Zemni and Bogaert (2009) explain that guided by international institutions, such as the International Monetary Fund (IMF), Morocco sought to create a flexible labour market through reduced public sector employment, deregulated minimum wage and dismantled social services. These actions made it a competitive supplier of cheap labour in the global economy even though 'unemployment, poverty, marginalisation and exclusion more and more constitute the face of Moroccan cities and rural areas alike' (Zemni \& Bogaert 2009, p. 94).

In places with free trade zones (FTZs) the expansion of a vulnerable low-wage population adds to this complex array of precarious labour conditions. With the largest FTZ in Morocco, Tangier is a paradigmatic case. Established in rapport to a legal minimum wage in the public discourse wages, in the FTZ are fair when compared to the rest of society - even high for the unskilled workers coming from informal employment in rural areas. But these wages (in cases less than a Euro per hour) have created situations of working poverty, particularly in the context of a rapidly rising cost of living. Evidencing this new form of exclusion, informal settlements have emerged in the outskirts and interstices of the FTZ; precarious shacks for workers are juxtaposed to modern and globally linked factories and facilities. These con- ditions, however, only hint at much larger housing shortages and urban fractures discussed below.

Uneven regional development, lack of metropolitan coherence and territorial fragmentation have been pervasive characteristics of Tangier since early modern days. In 1923, colonial and imperial powers established a militarily neutral and legislatively autonomous International Zone around the city while the rest of Morocco was divided into French and Spanish protectorates (Dalton et al. 1993a). Sharing the Zone were Europeans (French, Spanish, British, Italian, Belgian, Dutch and Portuguese), the United States and a local mandoub, or representative of the Sultan (1923-1956). Tangier was governed in an ad hoc laissez-faire manner that created problems with overlapping jurisdictions and administrative disjuncture. Free from international exchange controls, the city attracted a large in-flow of financial capital. Evidence of this special status is the large amounts of foreign gold deposited in local banks immediately after the Second World War (Ingérop 2002). A transnational class of bankers and merchants settled in and generated unprecedented wealth. These financial elites coexisted with a unique cultural mix of colonial elites, social outcasts, wandering artists, diverse Arab, Jewish and Berber locals (Pennell 2001). Table 2 shows that on the eve of Moroccan independence foreigners made up almost a quarter of Tangier's population though this ratio declined dramatically in the second half of the twentieth century. Concentrations were even higher in the central city. In the mid-1950s, two thirds of the population $(60,000$ residents) was foreign-born (Ingérop 2002, pp. 7-8). 
As a consequence of numerous, uncoordinated and competing planning efforts of international administration, Tangier developed a fragmented urban structure of uneven population densities and scattered enclaves of wealth. Also absent from Tangier is a welldelimited Jewish quarter (mellah) such as those found in Fez and Meknès (Dalton et al. 1993b). Nevertheless, years of unregulated urbanisation created a split between well-serviced dis-

Table 2. Population, Tangier, 1952-2004.

\begin{tabular}{lccc}
\hline Year & Population & $\begin{array}{c}\text { Foreign } \\
\text { population }\end{array}$ & Foreign $(\%)$ \\
\hline 1952 & 172,000 & 42,000 & 24 \\
1960 & 164,232 & 34,508 & 21 \\
1971 & 286,142 & 9,611 & 3 \\
1982 & 436,227 & 4,157 & 1 \\
1994 & 627,963 & 3,022 & 0.5 \\
2004 & 756,964 & 3,094 & 0.4 \\
\hline
\end{tabular}

Source: Own tabulation based on Dalton et al. (1993b); Direction de la Statistique (1971, 1982, 1994b, 2004, 2008). tricts in the European 'new town' and more recent informal settlements lacking formal infrastructure. Furthermore, upgraded settlements (the 'new medinas') were only marginally serviced by ad hoc utilities (DGUA 1997). Figure 2 shows high levels of fragmentation and heterogeneity even within districts. As is the case in other globalising cities, villas and informal shelters commonly co-exist in the same neighbourhood, if not side-by-side. Behind these fractures and juxtapositions is the post-independence exodus of wealthy expatriates and the subsequent Moroccan Jewish population. Their assets had been frozen but they still held ownership on urban land, which remained undeveloped or was informally occupied (DGU 1980).

Tangier underwent a prolonged period of stagnation after Moroccan independence and the fall of the Statute in 1956. Several factors contributed to economic decline during the ISI period lasting until the early 1980s. First, in the aftermath of nationalisation and loss of special international status gold deposits were massively withdrawn; banks and trading houses closed; and skilled workers erstwhile employed

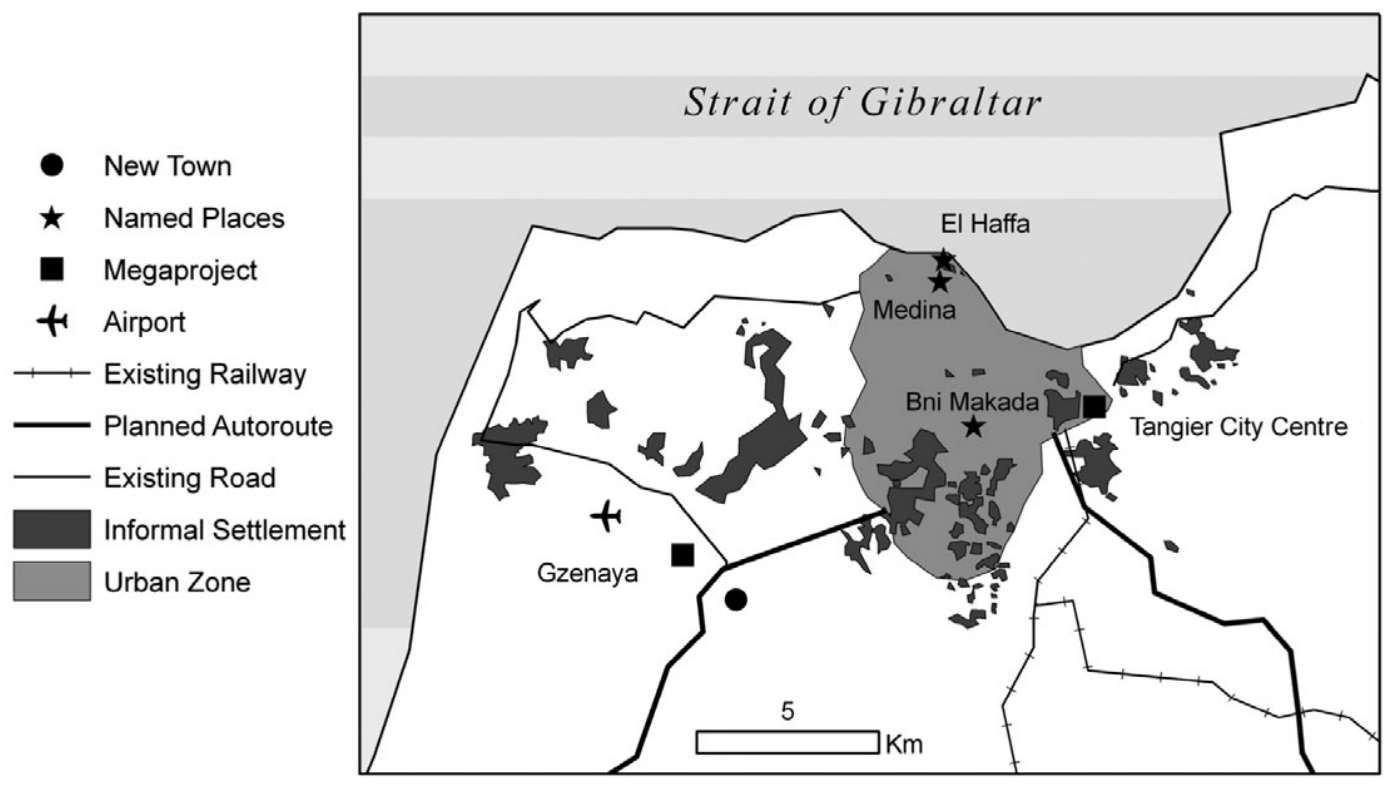

Figure 2. Central Tangier.

Source: Own drawing based on multiple schematic images from Tangier Urban Agency (Agence Urbaine de Tanger) and Tangier Mediterranean Special Agency. 
in the financial and trade sectors left en masse (Dalton et al. 1993b). In summary, the urban and regional economies were stripped of the colonial growth pillars. Second, few local benefits came from nationalisation and ISI efforts of the Moroccan state (rather weak compared to other MENA countries, such as Nasser's Egypt). Industrialisation-based urban growth was incompatible with Tangier's economic profile. In contrast to Casablanca, Tangier's Northern Region received scanty public industrial investments during the reign of Hassan II for seemingly political reasons and disputes, which remain unclear to this day (Oxford Business Group 2005). Lastly, the few industrial projects carried out through the 1970s were limited in scope, unco-ordinated and pollutive (Ahassad 1988; DGUA 1997).

Vigorous demographic growth provoked disorderly urban expansion in the midst of regional economic stagnation. Rural populations from throughout the Northern Region settled on the urban periphery tripling Tangier's population since the 1970s (See Table 2). Uncontrolled growth occurred largely outside the core because in-migrants chose to settle on lands deemed unsafe for development rather than risking eviction in centrally located vacant lots (DGU 1980). Yet due to large-scale population in-flows Tangier did not only expand outward. It also densified. This distinguishes Tangier from its surrounding region and makes it one of Morocco's densest urban areas (See Table 3). Urbanisation and densification also had a highly uneven distribution between central districts. While the city centre with a formal European-style urban layout grew at a

Table 3. Urbanisation rate, Tangier, 1982-2004.

\begin{tabular}{lccc}
\hline & \multicolumn{2}{c}{ Urbanisation } & Density \\
\cline { 2 - 3 } & $\begin{array}{c}\text { Tangier } \\
(\%)\end{array}$ & $\begin{array}{c}\text { Morocco } \\
(\%)\end{array}$ & $\begin{array}{c}\text { Tangier } \\
\left(\mathrm{Hab} / \mathrm{km}^{2}\right)\end{array}$ \\
\hline 1971 & 71 & 35 & - \\
1982 & 71 & 43 & 525.00 \\
1994 & 84 & 51 & 668.00 \\
2004 & 92 & 55 & 861.00 \\
\hline
\end{tabular}

Source: Own tabulation based on Direction de la Statistique (1982, 1994a, 2004, 2008). rate of 2.5 per cent between 1971 and 1981, the southern periphery, home to the large informal settlements at, for example, Bni Makada, recorded growth of nearly 19 per cent (DGUA 1997 , p. 8). In the face of such rapid expansion public authorities proved increasingly overwhelmed and ineffective in establishing adequate plans and controls, to address the growing crisis in housing, infrastructure and general service needs (DGUA 1997, p. 6).

Aggressive actions have been taken in the past two decades. As part of ambitious national housing plans, Tangier was able to upgrade and formalise many settlements (see e.g. MHU 2007 on the 'Cities without Slums' initiative that King Mohammed VI inaugurated in 2004). Unlike most cities in the less-developed world, Morocco has a unique case of informal settlement relocations that exceeds political rhetoric. Yet ongoing in-migration mars planning and development efforts and has led to the emergence of new informal settlements as older ones are upgraded. ${ }^{1}$ Furthermore, policy priorities have noticeably shifted with neoliberalisation. In the fields of housing and urban infrastructure (e.g. water supply), the impulse to harness globalisation's economic benefits prompts urban managers to privilege freemarket and speculative entrepreneurialism over subsidised service-oriented interventions (de Miras et al. 2007). The following section analyses the institutional context of this shift, which both parallels and departs from transitions to entrepreneurialism previously studied in cities of advanced industrial economies (Harvey 1989). The third section discusses large-scale development projects now seen as a panacea for reintegrating the fragmented city and allocating urban economic and social benefits.

\section{STATE RESTRUCTURING AND THE RISE OF URBAN ENTREPRENEURIALISM}

Contemporary patterns of territorial restructuring respond to specific plans and interventions by an elite cadre of entrepreneurial urban managers, who intend to harness economic globalisation's perceived benefits by capitalising on transnational investment flows, trade and tourism-related revenues. Understanding these practices is crucial to any robust explanation of 
Tangier's urban transformation. But it must also be understood that entrepreneurial managers operate within a framework of recalibrated state institutions that enable and even necessitate their actions. Such an explanation of shifts in urban and regional governance cannot be subsumed to mainstream accounts of administrative decentralisation. Reforms must rather be related to the neoliberal project to re-scale the territorial state apparatus and thereby promote and support new forms of transnational capitalist articulation. From this perspective Tangier mirrors other experiences of neoliberal restructuring in Morocco, the Middle East and North Africa region and across the contemporary world (Brenner 1999; Catusse 2008). Yet this case is also unique due to its specific political context and Morocco's troubled history of urban and regional development policies. The crown has played a central role in the re-scaling of the Moroccan state, refocusing developmental energies and concentrating investments in a handful of cities expected to act as global nodes. Yet, economic prioritisation came at the cost of further sidelining local accountability. Hegemonic institutions and officials are controlled by King Mohammed VI. Therefore, the concept of neoliberalisation is necessary but not sufficient to understand this specific process of state restructuring. Global trends are hybridised and even transformed by interactions with vernacular traditions, institutions and localised power relations.

Mounting post-independence development challenges help explain the emergence of both Tangier's entrepreneurialism and centralised state power consolidated in the hands of the King and his representatives. In the early period of nationalist development that lasted until the late 1960s, plans for economic growth paid little attention to economic and social disparities across regions. Industrial development depended on ISI (DCEP 1958, 1960, 1965). But the strategy failed and was soon replaced by a more geographically-nuanced approach seeking to take into account vastly differing regional needs. Actions remained centrally planned and royally dictated (DCEP 1968; DPDR 1973; Direction de la Planification 1978, 1981). This regionalism also encountered barriers, giving way to state-failure types of argu- ments. The Moroccan state was thought to lack a cadre of competent and skilled administrators capable of effectively communicating and fulfilling developmental demands. The 19811985 Economic and Social Plan (1981 Vol. I, p. 58) states the following:

Indeed, the need for human and financial resources made it impossible to direct necessary studies and devise a prospective vision for state territorial development. Now, lacking a formal vision articulating the spatial distribution of economic activities, human resources and infrastructures, it is difficult to engage voluntary and co-ordinated action in development.

Since the 1980s political and economic crises have fed off one another and allowed the King to entrench his power through local representatives expected to address the state of national emergency (Cherkaoui \& Ben Ali 2007). Administrative decentralisation was paired with privatisation, economic transnationalisation and increased adherence to international norms and free-trade agreements. King Mohammed VI has assumed a fundamental role in this process by brokering local and transnational interests. A new set of institutions was created under his tutelage and the influence of external investors and donors (primarily from the United States and the European Union), which promote globalisation through entrepreneurial urban development, particularly in strategic spaces such as the expanding city-region of Tangier.

The entrepreneurial organisations that have emerged to manage urban globalisation respond to a broad range of external demands for adjustment such as state decentralisation and participation. Free-market ideology argues that a large public sector discourages entrepreneurship, fuels the informal and black market economy, facilitates corruption and obfuscates which regulations need apply to different economic activities (Cherkaoui \& Ben Ali 2007). Indeed, the central government expanded after independence and was plagued by bureaucratic inefficiencies and corruption. Though marred by human and technical resource deficiencies, regional planning attempts sought to decentralise urban and regional economic growth management. In 
contrast, contemporary entrepreneurial institutions are nested within so-called participatory frameworks that equate democracy to 'good governance' and rely on forms of administrative rather than political decentralisation that give selective preeminence to managerial elites.

The three institutions at the forefront of urban management in Tangier are the superprefectural governorship (Wilaya), the urban agency (agence urbaine) and the communal council (conseil communal). The Wilaya was initially implemented ad hoc in Casablanca following the city's riots in 1981, but it has now evolved as a mechanism for regional metropolitan governance for the country's largest urban areas. King Mohammed VI employs a select group of politically loyal techno-walis (technogovernors) proven in private enterprise to promote neoliberal urban globalisation. Managers are circulated where they are most needed, which promotes merit-based accomplishments and presumably reduces corruption. (Catusse et al. 2007; Catusse 2008). The appointment of Mohammed Hassad to the Tangier-Tétouan region is exemplary. Known for leading a tourism renaissance in Marrakech, Hassad is seen as a crucial figure to steer Tangier toward a similar socio-cultural and economic resurgence. Hassad has jurisdiction over both Tangier-Assilah and the wider economic region, which leaves him in control of both the regional and prefectural budgets and executive functions.

A 1993 royal decree established urban agencies - though Tangier's was created later in 1998. Their primary role is the planning and elaboration of general plans or schémas directeurs. This gives agencies the authority to conceptualise and shape physical growth in accordance with local social and economic development goals. Their plans determine the intensity and extent of development, where growth shall occur, and which specific sectors will thereby benefit. In contrast, communal councils are still comprised of a democratically elected body of local representatives. But since the 2002 reforms, they explicitly aim to promote and encourage private investment via infrastructure development, economic activity zones and local business climate enhancement (DGCL 2003, Art 36.2).
To democratise and co-ordinate planning, the urban agency is legally mandated to liaise with the governor (representing state interests) and the communal council (representing local interests). The agency appears to mediate between the two, but it is in fact both arbiter and part since the urban planning director is also a representative of the central government. Furthermore, a representative of the Interior Ministry monitors the communal council. Hence, three individuals are vested with the central government's authority to locally safeguard its interests and make decisions for nearly one million inhabitants. Unveiling power relations in the governmental architecture problematises notions of contemporary state decentralisation and democratisation.

The reconfiguration of urban institutions also evidences a shift in managerial practices from a focus on the provision of basic services for locals to speculative entrepreneurialism targeting foreign investors (CRI 2009; DGCL 2004). The latter include an increased reliance on privatisation and fiscal incentives. Created in the post-1983 adjustment period, these institutions have the mission to make the city less dependent on state interventions. As illustrated in the following section, economic globalisation is in fact directed by and catered to an entrepreneurial elite of state managers who have assumed conspicuous roles in the planning and implementation of large-scale development plans and megaprojects. Noticeably, several of these actors have transitioned directly from the newly empowered private sector to prominent elected and appointed offices (Catusse 2008, p.137). Urban managers rely on special purpose agencies such as the TangierMediterranean Special Agency and the Société Marocaine d'Ingénierie Touristique (SMIT) to run megaprojects. These are generally chartered as public-private partnerships or publiclyowned private firms. They are characterised by their top-down approach and emphasis on governance procedures rather than direct democratic accountability (TMSA n.d.).

The largest megaprojects have emerged in recent years including: (a) the Tanger-Med Port (Tan-Med I); (b) an economic free zone; and (c) new towns developed beyond the edges of older built-up areas. Located $40 \mathrm{~km}$ east of Tangier, Tan-Med I was inaugurated in 2007. 
With total capacity for three million containers, a surface area of 80 hectares, and an investment of over 7.5 billion Euros, the completed port will be among the largest in the world. A port extension (Tan-Med II) is also projected for 2015. It will increase total container capacity to eight million (TMSA n.d.). The Tanger Free Zone was established in 1997, $10 \mathrm{~km}$ to the southwest of Tangier. It occupies a joint area of nearly 40 hectares and employs over 40,000 persons in more than 300 companies. Between 1999 and 2007 investment increased to over 500 million Euros (CRI 2009). Last, the new towns play an important role in the expansion of the globalising city-region. They are intended to provide the social infrastructure servicing main economic industries and to respond to systemic housing crises. They are also expected to transform the existing urban geography radically. For instance, the new town of Gzenaya Al Jadida near the Ibn Battuta Airport (the only one to have moved beyond an initial planning stage thus far) is projected to develop 12,000 housing units and ancillary facilities for an expected population of 60,000 residents. Less than 700 households lived on the original site according to the 2004 census (CRI 2009).

Megaprojects are primarily intended as mechanisms for economic globalisation catapulting the city-region to competitive positions within urban networks throughout the Middle East and North Africa (Stanley 2005). Yet urban managers are also challenged to leverage economic dynamism with the goal of overcoming Tangier's historic territorial fragmentation and uneven development. ${ }^{2}$ Figure 2 shows that megaprojects are planned as integrative base points for regional circulation and exchange. Nevertheless, while these new projects offer vast economic prospects, they also fail to adequately address the basic needs of the current city's inhabitants. The Tanger Free Zone employs thousands of local workers, yet unskilled labour is paid a mere 0.87 euro per hour (TFZ n.d.). New towns such as Gzenaya Al Jadida are expected to increase the stock of desperately needed housing, though many have voiced concerns that mortgage costs will be prohibitively expensive for those in need. Little attention has been paid to how the housing typology may be compatible with popular forms of econ- omic livelihoods (Borthwick 2009). Moreover, by continuing to prioritise external economic imperatives over historic, local needs, entrepreneurial megaprojects aggravate inequalities and create new forms of social polarisation and territorial splintering.

\section{TANGER CITY CENTER}

The Tanger City Center (TCC) initiative encapsulates central dynamics at play in the territorial and state restructuring of Tangier, as well as the entrepreneurial and even speculative character of these intertwined processes. TCC is a major redevelopment project of $175,000 \mathrm{~m}^{2}$ and an estimated global cost of 1.98 billion dirham. The case provides insight into the range of implicated public and private urban managers and the generally collaborative yet occasionally conflictive nature of their mutual relations and respective interests. Contrasts are also drawn between intended functions for the site in the globalising city-region and likely consequences of this project for the existing urban fabric.

Located on the eastern edge of the colonial urban grid built during the International Statute, TCC represents a new centrality for the expanding city-region. The project will house the city's first Western-style mall, a business centre, apartments, and two four- and five-star hotels. At three stories and $30,000 \mathrm{~m}^{2}$, Tanger City Mall will also be the first to cater to internationally recognised name-brand boutiques. The site was conceived as offering "the ability to wander and dine in perfect peace within the most refined ambiance' (TCC n.d, p. 7). It will have direct access to the hotels and train station. Tanger City Business will provide over $10,000 \mathrm{~m}^{2}$ of office space. The developer's expected future users and tenants include firms engaged with command and control functions. The exact number of expected employment generation remains undisclosed, but previous studies show this form of growth generates a bifurcated labour demand in which highly skilled, high-pay positions are filled by transnational expats while the remaining 'ancillary' low-wage workforce is composed of disadvantaged local populations (Sassen 2001). 
TCC is considered a key location in the emerging city-regional geography. In addition to producer service functions, TCC will be linked to megaprojects throughout TangierTétouan - such as, the Tanger-Med Port, to which there is direct train access less than 200 metres away. ${ }^{3}$ The Tanger City Residences will be composed of over 800 seaside apartments. This housing component is expected to represent a new image of urban living, yet also carry a premium cost in a city where housing is already unaffordable to most of its population. In Tangier, 40 per cent of residents build their homes themselves while an additional 20 per cent live in an inherited property (AREA 2003, p. 11). Last, with roughly $40,000 \mathrm{~m}^{2}$ Tanger City Hotels are designed to 'qualitatively and quantitatively reinforce the city's hotel capacity and consolidate its tourist and business objectives' (TCC n.d, p. 11). Hence, image is almost as important as capacity. Architecture is mobilised to emphasise international appeal at the heart of a globalising city-region, but has little to contribute to essential local needs.

TCC is under the remit of the Societé Marocain d'Ingénierie Touristique (Moroccan Tourism Engineering Company). SMIT is a government-owned corporation (société anonyme à capital public) focused on tourism development and capitalised at 41 million dirhams. SMIT's mission centres on the study, promotion, negotiation and implementation of tourism development projects. Compliant with King Mohammed VI's Vision 2010, SMIT seeks to bring 10 million tourists to Morocco and increase hotel capacity to 230,000 beds (MTA n.d., p. 10). Results thus far, show national tourism arrivals from 2001 to 2008 have increased from 4.4 to 7.9 million tourists. Created in 2008, SMIT consolidated three formerly separate development agencies: the Société Nationale d'Aménagement de la Baie de Tanger (National Bay of Tangier Development Company, SNABT), the Direction des Aménagements et des Investissements (Development and Investment Office) and the Société Nationale d'Aménagement de la Baie d'Agadir (National Bay of Agadir Development Company). Unlike local urban planning agencies and communal councils, Morocco's Ministry of Tourism directly manages SMIT. It has also expanded SNABT's former more limited jurisdiction by overseeing developments for the entire Northern Region. A general assembly of shareholders elects a supervisory board who then choose directors. The latter supervise regional offices in Tangier and Agadir.

SMIT's mission is to implement the Plan Mada'In (cities plan), a subsection of Vision 2010 specifically seeking to upgrade existing destinations through additional capacity for receptive tourism and the development of new tourist zones. Other guidelines include regional tourism development plans, which reflect efforts to diversify tourist offerings and reposition destinations. Tangier, Tétouan and Agadir are envisioned to specialise as 'seaside resorts', while other places such as Fez, Ouarzazate and Casablanca will act as 'cultural destinations' (MTA n.d., p. 11). But SMIT projects are also expected to play complementary roles to economic development initiatives and megaprojects seeking to globalise the city-region. This distinguishes the current drive from piecemeal tourist-oriented initiatives undertaken between the mid-1960s and early 1990s. Today, proactively subsidising projects is part of the agency's core actions - such as the $75 \mathrm{~m}$ dirhams directly contributed to TCC. More importantly, SMIT assembles and transfers land to developers in the form of below-market price 'symbolic offers'. 4

TCC must meet two diverging objectives. On the one hand, the project must embody distinctly Moroccan qualities to render the site unique and marketable in highly competitive tourist circuits that are based on place differentiation (TCG n.d., MTA n.d.). On the other hand, urban and architectural forms need to reflect Tangier's rising importance of as a node within global economic flows. A SMIT representative assigned to the project asserted: 'We want the Bay of Tangier to become the window to Africa and the gateway to Europe. ${ }^{5}$ Hence, TCC must provide a space to co-ordinate activities, such as a cosmopolitan central business district with direct access to the port, airport and free-trade zones of the city-region. However, in order to achieve a unique urban aesthetic marketable to global audiences, SMIT must appeal to transnational developers with expertise in delivering imported urban models. It therefore promotes the Bay of Tangier proactively at international 
real estate conferences in Europe, the Middle East and East Asia. ${ }^{6}$

Moreover, SMIT's development plans face both internal and external constraints. Internally, the agency finds a guiding lesson in the historic inability of its predecessor (SNABT) to plan, co-ordinate and develop the bay. A lack of qualified human resources to staff projects is often mentioned. Externally, cases of overbuilding such as southern Spain's Costa del Sol region advise against the consequences of pursuing uncontrolled, speculative development. They inspire Tangier's managers to formulate strict guidelines and procedures to protect the bay region from abusive overdevelopment and to create frameworks for the preservation of a local aesthetic in the central city. Yet, SMIT must also confront the reality that if regulations are too strict and incentives too weak, private foreign developers will not find the location attractive. In practice, the agency requires little more than a minimum investment commitment of 200 million dirhams and a 36-month project deadline from private investors.

The developer contracted for TCC is Inveravante, an international real estate development and industrial investment group based in $\mathrm{La}$ Coruña, Spain. Created in 2007, Inveravante has a diversified investment portfolio in energy, agribusiness and commercial and entertainmentoriented real estate. Its geographical realm of operations is broad and particularly focused on emerging markets in Europe, Latin America and North Africa. A company representative mentioned that Tangier's investment appeal lay in its tax incentives even though the regulatory system was as complex as in other parts of Morocco, and market size smaller than places such as Casablanca. $^{7}$

To develop TCC, both SMIT and Inveravante face heightened risks. Inveravante must conform to SMIT's specific development guidelines and architectural regulations. These threaten the firm's ability to maximise its desired profit margin as a global developer. Building codes may promote unmarketable design features, add unnecessary costs to the project and may not allow the firm to supply a product that is in greater demand elsewhere. For its part, SMIT maintains a preeminent position in Tangier, yet its highly territorialised space of dependency limits capacity to engage in highly competitive global markets for real estate investments and projects (Cox 1988). SMIT hence retains control over the symbolic (morphological) and managerial aspects of the project yet it is forced to provide large fiscal incentives and tax exemptions to the developer so that the project remains lucrative and attractive. SMIT's local centrality is contingent upon its capacity to successfully mediate with such external actors and maintain an in-flow of foreign investments. By the same token, this position makes it more impervious to residents' demands or any concerns to extract wider community benefits or planning gains from the project.

The resulting consequences of such redevelopment are manifold for the existing city. TCC and other real estate projects appeal to a privileged minority with the means to shop at Western style luxury malls that remain prohibitive to most others. While a national and urban housing crisis continues, state resources are spent on attracting foreigners rather than critically assessing or addressing basic needs of residents. TCC will anchor a new city-regional transportation infrastructure linking globalised economic nodes, but it will peripheralise already disadvantaged areas such as the old medina by moving the city's core further to the east. While this is part of a generalised infrastructure upgrading, including road construction and improvement, little investment is put on enhancing the mobility of those without means. For example, residents of populous yet peripheral areas such as Bni Makada depend on public transportation even though the sector receives a fraction of the local budget. In a recent infrastructure upgrade, public transportation was allocated only 80 million dirhams, or 3 per cent of Tangier's total budget (CRI 2009, pp. 24-25).

Furthermore, though no major evictions occurred at the TCC site, the pursuit of a sanitised modernity that it embodies also leads to the neglect and displacement of existing populations and activities. For instance, in the medina, tourism-oriented public expenditures on renovating the Kasbah's façade and walls (100 million dirhams) largely exceeded funding of programmes for settlement relocations (20 million dirhams). 


\section{CONCLUSIONS AND FURTHER RESEARCH}

This paper explored the manifold implications to the territorial and state restructuring of Tangier over the past decades in a context of urban entrepreneurialism and neoliberal globalisation. The analysis showed impressive economic dynamism, demographic growth, regional expansion and deepening transnational connections. Tangier is transforming itself into a global city-region with a Mediterranean insertion. With such restructuring embedded in the wider transformation of the Moroccan state and urban system, a new era has emerged. Current dynamics are distinct from post-independence developmentalism and rather echo characteristics of the transnational enclave under colonial rule. Yet the new growth impulse has not been able to overcome social and spatial challenges inherited from the city's colonial past. Furthermore, such a growth model generates novel social inequalities and spatial ruptures that aggravate problematic urban conditions.

In many ways, Tangier's story is one known to numerous cities around the world. This restructuring has been particularly scrutinised in the context of advanced industrialised nations in North America and Western Europe (See e.g. Brenner \& Theodore 2002). However, the intrinsic value of this case study is its adoption of some general dynamics within its very local and regional specificities. While stated goals, modalities and outcomes of urban development follow the former, the latter is evidenced by a monarch-centric governance system and complex subordinate relations to multiple economic, political and cultural hegemons. Therefore, while the main concern of this study was the specific urban and regulatory transformations of Tangier, the process of city-regional restructuring presented here also contributes towards a comparative and relational urban research agenda.

This agenda can be advanced through multiple controlled comparisons intended to further dissect the generalisable particularities of Tangier (Soja 2000; Brenner 2001; Nijman 2007). Comparative ranges may be established regionally. The case may be seen as one path towards urban globalisation taking place within the specific regulations and politics of Arab states in the Middle East and North Africa (Stanley 2005). Yet, Tangier can also be compared to other sites 'marginal' to Europe, which despite enhanced articulations remain peripheral and are increasingly placed under the regulatory scrutiny of the European Union (e.g. due to issues of unauthorised migration). Furthermore, Tangier may fit urban categories such as those of the border, gateway and entrepôt city. The comparative realm could then be extended to places such as Tijuana and Panama City or even Miami and Singapore. Finally, Tangier may be seen as an erstwhile colonial/international and now globalising city-region. Aspects of external relationality and domestic positioning would then make it comparable to cases with similar historical trajectories such as Shanghai.

Regarding mounting challenges of inscribing collective meaning into the built environment, insightful comparative examples can be found in globalising cities of Latin America. These have undergone similar processes of crisis-generated restructuring and ensuing globalisation after unsuccessful attempts of import-substitution industrialisation. Myers and Dietz (2002, p. 24) argue that statesponsored city development initiatives are now less effective in inscribing collective meanings and civic values into built environments. Hence it has become more difficult to instrumentalise such interventions as sources of political legitimacy. The research presented herein indicates that in Tangier this difficulty has less to do with the subject matter being textualised than the multiplicity of local and extra-local audiences and stake-holders to whom entrepreneurial urban managers must now respond. This conjunction renders the deliverance of a clearly localised narrative almost impossible but at the same time it reaffirms the strong nexus between urban development and state power, which now rather derives from the ability to articulate interventions with polyvalent and glocalised signifiers. Further comparative and relational research could help disentangle the factors intervening in such tensions and their localised resolutions and outcomes.

Additional comparisons between Moroccan cities and those in Latin America can be made in terms of the particular roles that growing 
transnational conglomerates based in Spain play in their urban globalisation. Such actors have invested heavily in real-estate development projects throughout both regions as well as on infrastructure, utility companies, tourism and specialised commercial sectors. They hence, mediate the relational access of these cities to transnational capital, entrepreneurial know-how and consumer markets through their specific logics, imperatives and constraints. Further research is needed to establish how these corporations may depart in their practices from those based in the US and larger European economies.

Finally, Tangier and other cases of top-down urban development and ensuing social and spatial inequalities beg the question of how civil society may be responding, and what forms of resistance may be emerging underneath a seemingly unchallenged state hegemony. In the case of comparative analysis, the specific state formation for each urban process must not be overlooked and the multifarious and complex alliances and compromises between state and social actors taken into account. Such research may enhance the field of comparative urban political economy but also acquire local importance by helping to understand how the restructuring of Tangier could be steered in directions that are more socially inclusive and spatially just.

\section{Notes}

1. It has long been recognized that the extent of informal settlements in Tangier is underestimated in official statistics (Urba Systems 1999, p. 13). This is further aggravated by the constant redefinition of what constitutes informal housing in census reports.

2. Interview with SMIT representative who requested to remain anonymous, conducted on 18 June 2009.

3. Interview with Inveravante company representative who requested to remain unnamed, conducted on 20 July 2009.

4. Interview with SMIT representative who requested to remain anonymous, conducted on 18 June 2009.

5 Interview with SMIT representative who requested to remain anonymous, conducted on 18 June 2009.
6. Communication with Moroccan Ministry of Tourism representative who requested to remain unnamed on 15 October 2009.

7. Communication with Inveravante's company representative on 15 October 2009.

\section{REFERENCES}

Ahassad, S. (1988), Diagnostic de l'Urbanisation à Tanger. (Master's Thesis, Ecole d'Architecture, Centre Habitat Tiers Monde, Marseille-Luminy).

Atelier De Recherche, D'etude et D'Architecture (AREA) (2003), Powerpoint presentation for the Enquête de logement à Tanger: Sommaire, Rabat-Agdal.

Borthwick, M. (2009), Moroccan Efforts to Replace Slums. BBC News. Available at $<$ http://news.bbc. co.uk/2/hi/business/8266403.stm>. Accessed 21 September 2009.

BRENNER, N. (1999), Globalization and Reterritorialization: The Rescaling of Urban Governance in the European Union. Urban Studies 36, pp. 431451.

Brenner, N. (2001), World City Theory, Globalization and the Comparative-historical Method: Reflections on Janet Abu-Lughod's Interpretation of Contemporary Urban Restructuring. Urban Affairs Review 36, pp. 124-147.

Brenner, N. \& N. Theodore (2002), Spaces of Neoliberalism: Urban Restructuring in North America and Western Europe. Oxford: Blackwell.

CAtusse, M. (2008), Le Temps des Entrepreneurs? Politique et Transformations du Capitalisme au Maroc. Paris: Maisonneuve \& Larosse.

Catusse, M., R. Cattedra \& M.J. Janati (2007), Decentralisation and its Paradoxes in Morocco. In: B. Driesken, F. Mermier \& H. Wimmen, eds., Cities of the South. London: Saqi Books.

Centre Regional d'Investissement (CRI) (2009), Grands Chantiers de la Région Tanger-Tétouan: Les Nouveau Défis de la Région. CRInfo Nord 2, pp. 14-22.

Cherkaoui, M. \& d. Ben Ali (2007), The Political Economy of Growth in Morocco. The Quarterly Review of Economics and Finance 46, pp. 741-761.

Cohen, S. \& L. Jaidi (2006), Morocco: Globalisation and Its Consequences. London: Routledge.

Cox, K.R. (1988), Spaces of Dependence, Spaces of Engagement and the Politics of Scale or: Looking for Local Politics. Political Geography 17, pp. 1-23.

Dalton, R.T., R.E. Pearson \& H.R. Barrett (1993a), The Diplomatic Geography of Tangier. 
In: M. Refass, ed., Tanger: Espace, Economie et la Société. Tangier: Université Mohammed V, Université Abdelmalek Es-Saâdi.

Dalton, R.T., R.E. Pearson \& H.R. Barrett (1993b), The Urban Morphology of Tangier. In: M. Refass, ed., Tanger: Espace, Economie et la Société. Tangier: Université Mohammed V, Université Abdelmalek Es-Saâdi.

De Miras, C., J. Le Tellier \& A. Benmansour (2007), Le Modèle Marocain de Gouvernace de l'Eau Potable. L'Initiative Nationale pour le Développement Humain dans la Construction Progressive du Marché de l'Eau. Critique Economique, 20, pp. 1-9.

Direction de la Planification (1978), Plan de Développement Economique et Social 1978-1980. Rabat: Haut Commissariat au Plan.

Direction de la Planification (1981), Plan de Développement Economique et Social 1981-1985. Rabat: Haut Commissariat au Plan, Direction de la Planification.

Direction de la Statistique (1971), Recensement Général de la Population et de l'Habitat. Rabat: Haut Commissariat au Plan, Direction de la Statistique.

Direction de la Statistique (1982), Recensement Général de la Population et de l'Habitat. Rabat: Haut Commissariat au Plan, Direction de la Statistique.

Direction de la Statistique (1994a), Annuaire Statistique, Région du Nord-Ouest. Rabat: Haut Commissariat au Plan, Délégation Régionale du NordOuest, Direction de la Statistique.

Direction de la Statistique (1994b), Recensement Général de la Population et de l'Habitat. Série Provinciale, Tanger. Rabat: Haut Commissariat au Plan, Direction de la Statistique.

Direction DE LA Statistique (2000), Annuaire Statistique Régionale Tanger-Tétouan. Rabat: Ministère de la Prévision Economique et du Plan, Délégation Régionale de Tanger-Tétouan.

Direction De LA Statistique (2004), Recensement Général de la Population et de l'Habitat. Rabat: Haut Commissariat au Plan, Direction de la Statistique.

Direction De LA Statistique (2005), Annuaire Statistique Régionale Tanger-Tétouan. Rabat: Haut Commissariat au Plan, Direction de la Statistique.

Direction DE LA Statistique (2007), Annuaire Statistique Régionale Tanger-Tétouan. Rabat: Haut Commissariat au Plan, Direction de la Statistique.

Direction de la Statistique (2008), Monographie de la Région Tanger-Tétouan. Tanger: Haut Commissariat au Plan, Direction de la Statistique.
Direction de la Statistique (2010), Indice de la Coute de Vie Annuel par Group pour la Ville de Tanger. Haut Commissariat au Plan, Direction de la Statistique. Available at <http://www.hcp.ma/ frmInd.aspx?id=0902041001\&vara=10>. Accessed 9 February 2010.

Direction du Plan et Developpement Regionale (DPDR) (1973), Plan de Développement Economique et Social 1973-1977. Rabat: Haut Commissariat au Plan, Direction du Plan et Développement Régional.

Direction Generale de L'Urbanisme (DGU) (1980), Schéma Directeur d'Aménagement Urbain de Tanger. Rabat: Ministère de l'Intérieur, Direction Générale de l'Urbanisme.

Direction Generale de L'Urbanisme ET DE L'Architecture/Agencia Espagnola de CoopERACION INTERNATIONAL (DGUA) (1997), Schéma Directeur d'Aménagement Urbain de Tanger: Rapport Final. Rabat: Ministère de l'Intérieur, Direction Générale de l'Urbanisme, de l'Architecture et de l'Aménagement du Territoire.

Direction Generale des Collectivites Locales (DGCL) (1993), Loi N¹-93-51 du 10 Septembre 1993 Instituant les Agences Urbaines. Rabat: Publication du Centre de Documentation des Collectivités Locales.

Direction Generale des Collectivites Locales (DGCL) (2003), Loi $N^{\circ} 78.00$ Portant Charte Communale. Rabat: Publication du Centre de Documentation des Collectivités Locales.

Direction Generale des Collectivites Locales (DGCL) (2004), Loi $N^{\circ} 79.00$ Relative à l'Organisation des Collectivités Préfectorales et Provinciales. Rabat: Publication du Centre de Documentation des Collectivités Locales.

Division de la Coordination Economique et DU Plan (DCEP) (1958), Plan de Développement Economique et Social 1958-1959. Rabat: Délégation Générale à la Promotion Nationale et au Plan. Division de la Coordination Economique et du Plan.

Division de la Coordination EconomiQue et DU Plan (DCEP) (1960), Plan de Développement Economique et Social 1960-1964. Rabat: Délégation Générale à la Promotion Nationale et au Plan. Division de la Coordination Economique et du Plan.

Division de la Coordination EconomiQue ET DU Plan (DCEP) (1965), Plan de Développement Economique et Social 1965-1967. Rabat: Délégation Générale à la Promotion Nationale et au Plan. 
Division de la Coordination Economique et du Plan.

Division de la Coordination Economique et du Plan (DCEP) (1968), Plan de Développement Economique et Social 1968-1972. Rabat: Ministère des Affaires Economiques du Plan et de la Formation de Cadres. Division de la Coordination Economique et du Plan.

Graham, S. \& S. Marvin (2001), Splintering Urbanism: Networked Infrastructures, Technological Mobilities and the Urban Condition. London: Routledge.

Grant, R. (2009), Globalising City: The Urban and Economic Transformation of Accra, Ghana. Syracuse, NY: Syracuse University Press.

Grant, R. \& J. NiJMan (2002), Globalisation and the Corporate Geography of Cities in the LessDeveloped World. Annals of the Association of American Geographers 92, pp. 320-340.

Grant, R. \& J.R. Short (eds.) (2002), Globalisation and the Margins. New York: Palgrave MacMillan.

Harvey, D. (1989), From Managerialism to Entrepreneurialism: The Transformation in Urban Governance in Late Capitalism. Geografiska Annaler B, 71(1), pp. 3-17.

Ingérop/Bet Sciences Urbaines et de DevelopPement (2002), Etude de l'Aire Métropolaine du Bipôle Tanger-Tétouan: Diagnostic territorial état des lieux. Tangier: Direction de l'Aménagement du Territoire.

Machimura, T. (2003), On the Corner of Diverse/ Reverse Globalisation: The Third Stage of Global 'Urban Studies'. International Journal of Urban and Regional Research 27, pp. 957-959.

Ministere du Tourisme et DE L'Artisanat (MTA) (n.d.), Tourism Investment in Morocco: A Golden Star Opportunity. [Brochure] Rabat: Ministère du Tourisme et de l'Artisanat.

Ministere Delegue Charge de l'Habitat et de L’Urbanisme (MHU) (2007), Projets d'Habitation et d'Urbanisme Lancés ou Inaugurés par Sa Majesté le Roi Mohammed VI. Rabat: Ministère de l'Habitat et de l'Urbanisme.

Moulaert, F., A. Rodriguez \& E. Swyngedouw (2003), The Globalized City: Economic Restructuring and Social Polarisation in European Cities. Oxford: Oxford University Press.
Myers, D.J. \& H.A. Dietz (2002), Capital City Politics in Latin America: Democratisation and Empowerment. Boulder, CO: Lynne Reinner Publishers.

Nijman, J. (2007), Place-particularity and 'Deep Analogies': A Comparative Essay on Miami's Rise as a World City. Urban Studies, 28, pp. 92-107.

ONG, A. (2006), Neoliberalism as Exception: Mutations in Citizenship and Sovereignty. Durham, NC: Duke University Press.

Oxford Business Group (2005), Northern Lights. Emerging Morocco, pp. 95-113.

Pennell, C.R. (2001), Morocco since 1830: A History. New York: New York University Press.

Robinson, J. (2006), Ordinary Cities: Between Modernity and Development. London: Routledge.

SAssen, S. (2001), The Global City: Tokyo, New York, London. Princeton, NJ: Princeton University Press. Scotт, A.J. (2001), Global City-regions: Trends, Theory, Policy. New York: Oxford University Press.

Short, J.R., Y. Kim, M. Kuss \& H. Wells (1996), The Dirty Little Secret of World Cities Research: Data Problems in Comparative Analysis. International Journal of Urban and Regional Research 20, pp. 697719.

Soja, E.W. (2000), Postmetropolis: Critical Studies of Cities and Regions. Oxford: Blackwell.

Stanley, B. (2005), Middle East City Networks and the 'New Urbanism'. Cities 22, pp. 189-199.

Tanger City Center (TCC) (n.d.) Tanger City Center. [Brochure]. Tangier: Inveravante.

TAnger Free Zone (TFZ) (n.d.), Tanger Free Zone: Un Site Privilégié, Un Cadre Idéal Pour Développer Vos Affaires. [Brochure]. Tangier: Tanger Free Zone.

Tangier Mediterranean Special Agency (TMSA) (n.d.), Port Tanger Med: L'Excellence au Service de la Croissance. [Brochure]. Tangier: Tangier Mediterranean Special Agency.

Urba Systems (1999), Plan Locale d'Habitat et de Développement Urbain: Agglomération de Tanger. Rabat: Ministère de l'Habitat, Direction Régionale de l'Habitat et de Développement Urbain.

Zemni, S. \& K. Bogaert (2009), Trade, Security and Neoliberal Politics: Whiter Arab Reform? Evidence from the Moroccan Case. The Journal of North African Studies, 14, pp. 91-107. 